DOI

\title{
ПЕРШИЙ ДОСВІД ПРОВЕДЕННЯ МАСОВОГО СКРИНІНГУ СТАНУ ЗДОРОВ'Я НАСЕЛЕННЯ В СІЛЬСЬКИХ РАЙОНАХ ХМЕЛЬНИЦЬКОЇ ОБЛАСТІ
}

\author{
Є. В. Найштетік, І. А. Чайковський ${ }^{1}$ \\ БФ «Перший добровольчий мобільний шпиталь» \\ 1 Інститут кібернетики імені В. М. Глушкова НАН України
}

\section{THE FIRST EXPERIENCE OF MASS SCREENING OF THE POPULATION HEALTH IN RURAL AREAS OF KHMELNITSKY REGION}

\author{
Ye. V. Nayshtetik, I. A. Chaykovskyi ${ }^{1}$ \\ The first volunteer mobile hospital \\ 1 V. M. Glushkov Institute of Cybernetics of NAS of Ukraine
}

Вступ. Забезпечення доступу до ресурсів охорони здоров'я та впровадження профілактичних методів $є$ одним 3 найважливіших завдань сфери громадського здоров'я не лише в Україні, а й в інших країнах із перехідною економікою. Саме тому постійний пошук технологій, здатних відносно дешево виявити клінічно значимі ризики 3 вірогідністю більше 50 \%, не зупинєються вже впродовж щонайменше трьох десятиліть.

Найбільшою причиною смертності людства $\epsilon$ серцево-судинні захворювання (СС3), що в різних популяціях досягають до 70 \%. Зокрема Україна $є$ постійним очільником такого антирейтингу в світі. Через це проблема ранньої діагностики та профілактики саме СС3 виходить на перший план.

Результати та їх обговорення. Наприкінці вересня 2015 року силами БФ «Перший добровольчий мобільний шпиталь», БФ «Зміцнення громад», Першого національного аграрного кооперативу та ТОВ «Кардіолайз» розпочато масштабний скринінг серцево-судинних ризиків серед сільского населення Хмельницької області.

Скринінг здійснюється за допомогою сучасного програмно-апаратного комплексу «Кардіо+_П», розробленого в Інституті кібернетики імені В. М. Глушкова НАН України та виготовленого ТОВ «Метекол».

Охоплюючи лише тих, хто добровільно звернувся за консультацією, проект ставить за мету створити базу даних кардіографічних досліджень та автоматично кодованих результатів щонайменше 20000 осіб. Первинний аналіз даних відбувається за більш ніж 260 показниками електрокардіограми, серед яких Мінесотське кодування, кодування Сельвестру, CIIS, код QRS, а також група показників оцінювання варіабельності ритму серця. Використовуються також оригінальні електрокардіографічні ознаки, що складають так званий запропонований нами Універсальний код. Окремо слід згадати електрокардіографічні ознаки, що призначені спеціально для визначення вірогідності виникнення серцево-судинних подій. Додатково всім особам, що звернулися, вимірювали артеріальний тиск та цукор крові. Проект дасть можливість оцінити економічні параметри масового застосування сучасних електрокардіографічних програмно-апаратних комплексів із розвинутим програмним забезпеченням для первинної профілактики СС3, розширити доступ до ресурсів охорони здоров'я в сільській місцевості, та, загалом, знизити ризики виникнення життєвозагрожуючих захворювань. Практична реалізація цього задуму ясно демонструє високий попит подібної послуги населенням сільських районів.

Висновки. Подальше використання наведених технологій значно розширить апаратну базу для застосування інструментальної телемедицини в сільській місцевості, що стало можливим завдяки здешевленню супутникових систем зв'язку за останні три роки. 